\title{
An In Vitro Model for the Study of Human Bone Marrow Angiogenesis: Role of Hematopoietic Cytokines
}

Laurent Pelletier, Jacques Regnard, Dominique Fellmann, and Pierre Charbord

Institut d'Etude et de Transfert de Gènes (LP), Laboratoire de Physiologie-Médecine, Faculté de Médecine (JR), Laboratoire de Neuroendocrinologie morpho-fonctionnelle, Faculté de médecine (DF), and Laboratoire d'étude de l'hématopoïse, ETS de Franche-Comté (PC), Besancon, France

SUMMARY: This study describes a human bone marrow endothelial cell culture in which endothelial cells are organized into capillary tubes. These endothelial cells were positive for von Willebrand Factor, expressed CD34, CD31, and L-fucose residues, took up acetylated low-density lipoproteins, contained Weibel-Palade bodies, and were ensheathed in a basal lamina (which included laminin $\beta 1, \mathrm{EDa}+$ and EDb + fibronectin, and collagen type iv). Pericytes expressing $\alpha$-smooth muscle $(\alpha$-SM) actin were spatially associated with the capillary tubes and there was a highly significant correlation between the number of capillary tubes and pericytes. In this model, basal angiogenesis was found to be vascular endothelial growth factor (VEGF)-dependent, because neutralization of endogenous VEGF induced a dramatic regression in the number of tubes. However, the presence of $\alpha$-SM actin-expressing pericytes in the linings of endothelial tubes partially prevented the VEGF-neutralized tube regression. We also observed that nitric oxide production contributed to basal angiogenesis and that upregulation of nitric oxide increased the number of tubes. Tube numbers also decreased when antibodies neutralizing the integrin $\alpha \mathrm{v} \beta 5$ were applied to the cultures. Moreover, addition of any of the hematopoietic cytokines, erythropoietin, stem cell factor, granulocytic colony stimulating factor, or granulomonocytic colony stimulating factor induced a highly significant increase in tube formation. When erythropoietin and granulocytic colony stimulating factor were added, this increase was larger than the maximum increase observed with VEGF. Thus, we have described an in vitro model for human bone marrow angiogenesis in which pericytes and basal lamina matrix were associated with endothelial cells and formed fully organized capillary tubes. In this model, cytokines known to regulate hematopoiesis also seemed to be mediators of angiogenesis. This culture system may therefore prove to be a valuable tool for the study of hematopoietic cytokines on angiogenesis. (Lab Invest 2000, 80:501-511).

$$
T^{\text {ton }}
$$
he marrow hematopoietic microenvironment comprises the non-hematopoietic elements found in marrow cords, ie, adipocytes, endosteal cells, and cells forming the vascular network (for review, see Charbord, 1999). Vascular network cells are luminal endothelial cells or abluminal cells (pericapillary pericytes, parasinusal myoid cells, and vascular smooth muscle cells from the media of arterioles). Pericapillary pericytes and myoid cells are likely to play a central role in marrow homeostasis because they are associated with both endothelial and hematopoietic cells (Charbord et al, 1996; Galmiche et al, 1993).

Because hematopoiesis takes place in mammals in an extravascular location, mature blood cells must cross the vascular wall. Both endothelial cells and abluminal cells contribute to the control of the release

Received November 16, 1999.

This work was supported by grants from INSERM (CRI N950401) and from Fonds d'organisation et de recherche en transfusion sanguine. $L$. Pelletier was supported by a grant from the Ministère de l'Enseignement Supérieur et de la Recherche.

Address reprint requests to: Dr. Laurent Pelletier, E.T.S. de Franche Comté, Laboratoire d'étude de l'hématopoïse, 1, BD A. Fleming, BP 1937, 25030 Besancon Cedex, France. Fax: 330381 614 617; E-mail: l.pelletier@voila.fr of hematopoietic cells (Lichtman, 1984), and in pathologic conditions, the decrease in endothelial cell covering by adventitial reticular cells might favor the release of hematopoietic cells into the bloodstream (Wilson and Tavassoli, 1994).

In vivo angiogenesis occurs in rare physiologic conditions such as menstruation and wound healing. On the contrary, it is observed in numerous pathologic states such as tumoral development and chronic inflammation (for review, see Folkman, 1996; Jackson et al, 1997). Bone marrow angiogenesis has been reported in myelofibrosis (Reilly et al, 1985) and in acute lymphoblastic leukemia (Perez-Atayde et al, 1997). Myelofibrosis (in case of agnogenic myeloid metaplasia or after polycythemia vera) is caused by mesenchymal cell proliferation secondary to the emergence of a neoplastic clone (Adamson et al, 1976; Jacobson et al, 1978). The proliferation of the fibroblastic cells is partially caused by platelet-derived growth factor (PDGF), a well known angiogenic factor (Groopman, 1980). Endothelial cells also proliferate in this disease (Reilly et al, 1985); this proliferation might also be induced by PDGF (Ishikawa et al, 1989). In acute lymphoblastic leukemia, the bone marrow vascular network density and basic fibroblast growth factor (bFGF) levels in urine are significantly increased. 
The involvement of vascular endothelial growth factor (VEGF) in acute lymphoblastic leukemia also seems likely because leukemic cells synthesize and release this angiogenic factor (Fiedler et al, 1997).

Increased marrow angiogenesis is associated with increased bone marrow blood flow (Van Dyke et al, 1970). This might be caused by the secretion of hematopoietic cytokines because administration of granulocytic colony stimulating factor (G-CSF) or erythropoietin (EPO) induces an increase in marrow blood flow in experimental animals (Iversen et al, 1992). These data lead to the conclusion that, under specific pathological conditions, marrow endothelial cells might shift from a resting phenotype to an angiogenic phenotype. This is probably secondary to the growth of neoplastic or mesenchymal cells.

In this study, we describe an in vitro model of angiogenesis where endothelial cells form capillary tubes comprising basal lamina and surrounding pericytes. Basal angiogenesis is dependent on the presence of VEGF and is strongly upregulated by growth factors involved in the modulation of hematopoiesis. These data further suggest a potential link between marrow angiogenesis and hematopoiesis via common cytokine regulators produced by stromal cells.

\section{Results}

\section{Culture Initiation and Maintenance}

Thirty-six hours after the selected cells were plated, adherent cells were observed forming foci of 5 to 12 cells. The plot of foci number versus the number of cells seeded was linear (13 cultures analyzed; $r^{2}>$ 0.99). At high concentrations of plated cells, foci were too numerous to precisely count. At lower concentrations of plated cells, we found an average of one colony per 8000 cells. Adherent cells were spindleshaped, had dark cytoplasm, and their nucleus contained two or three nucleoli. These cells took up dil-acetylated-low density lipoproteins.

After 72 hours of culture, the foci also contained starry cells. These cells were widespread and had clear cytoplasm. The cultures were confluent after one to two weeks and consisted of a monolayer of elongated cells. Many of these cells were linearly arrayed, forming tubes.

After reaching confluence, the cultures were treated with trypsin. The resulting single cell suspension was cultured again in the same medium. After a few days, tube formation was observed again. Such cultures could be maintained for up to five passages and sixty days with persistent tube formation throughout the culture period.

\section{Endothelial Cells are Organized in Tubes}

Cells forming tubes were identified as endothelial cells. Their cytoplasm contained a granular material which was immunoreactive to an antibody to von Willebrand Factor (Fig. 1), and similar, but spatially distinct, labeling was observed after incubation with acetylated low-density lipoproteins. Such endothelial
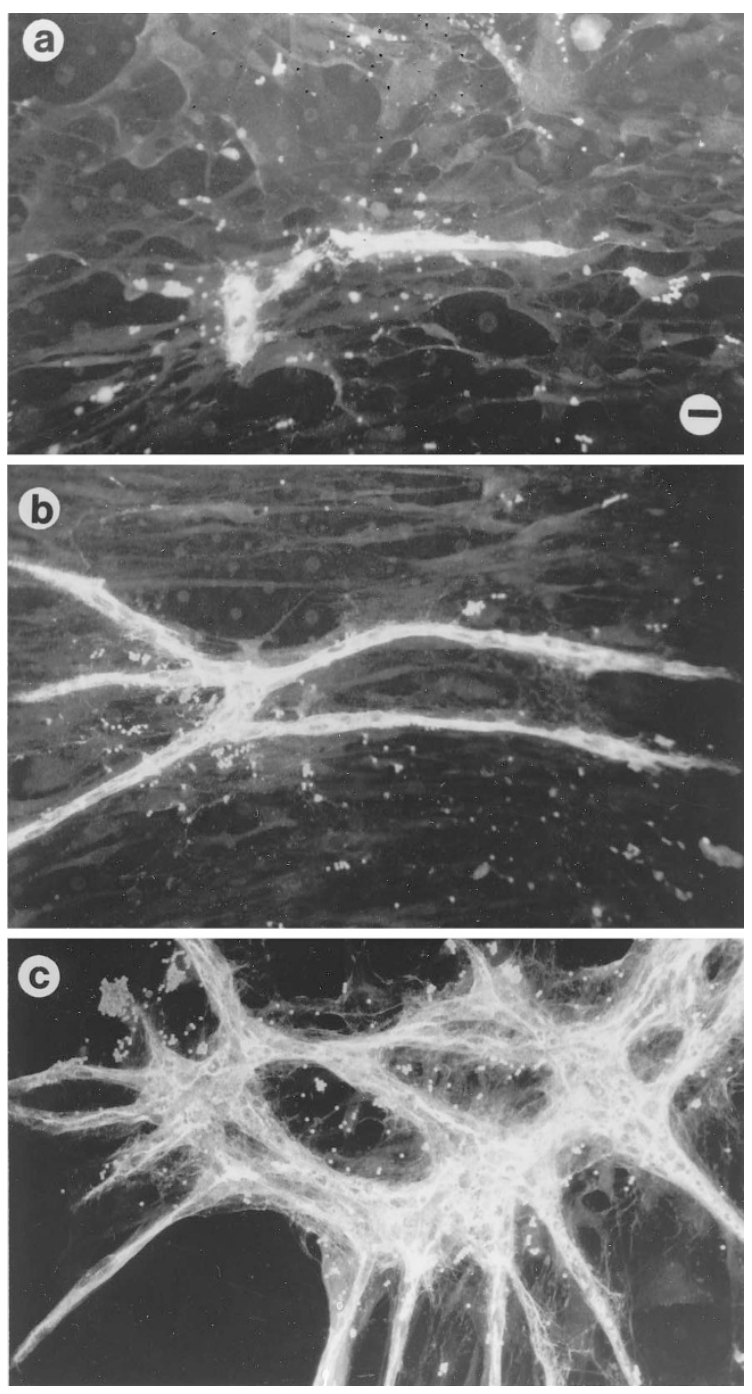

Figure 1.

Organization of endothelial cells. a, b, and c show different levels of tube development after labeling with a TRITC-conjugated antibody to von Willebrand Factor (vWF), corresponding to passage 1 (a, 21 days in culture), passage 2 (b, 30 days in culture), and passage 3 (c, 49 days in culture). At passage 1 (a), the few endothelial cells observed are already aligned in a tubular configuration. At passage 2 (b), five branching tubes form a network. At passage 3 (c) the network is dense and anastomosing. At each passage, the layers were trypsinized and the resulting cell suspension was cultured. The generation of the network resulted, therefore, from the growth of endothelial cells. Scale bar $=10 \mu \mathrm{m}$.

cells always seemed to be organized in tubes; we never observed these immunoreactive cells forming cobblestone areas. The endothelial cell membrane was generally smooth, closely apposed, without any long finger-like processes, expressed CD31 and CD34 antigens, and bore $\alpha$ - $L$ fucose residues which bound Ulex europaeus agglutinin-1 (Fig. 2). The cells also expressed $\alpha v \beta 3$ integrins and Intercellular Cell Adhesion Molecule-2, but not Intercellular Cell Adhesion Molecule-1 or Vascular Cell Adhesion Molecule.

At the first culture passage, we measured the number of von Willebrand factor-immunoreactive tubes per square centimeter. The number of tubes ranged from 20 to more than 600 per square centimeter. For 

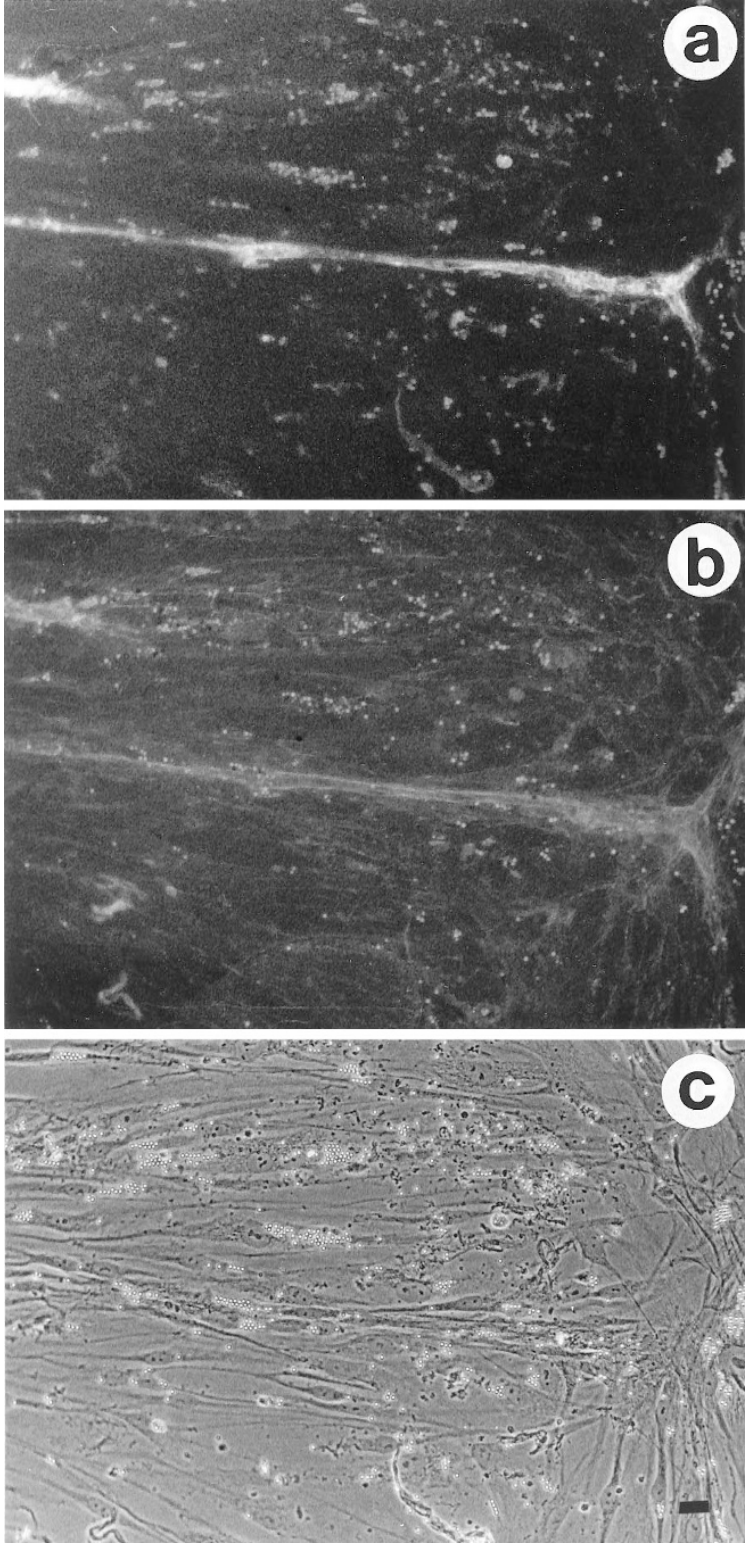

Figure 2.

Ensheathment of endothelial tubes in EDb + fibronectin matrix. Doublelabeling with a TRITC-conjugated polyclonal antibody to VWF (a) and with a FITC-conjugated monoclonal antibody to EDb + fibronectin (b). Corresponding phase-contrast photomicrograph (c). A network of $\mathrm{EDb}+$ fibronectin is present where the VWF immunoreactive endothelial tube is observed. Scale bar $=10$ $\mu \mathrm{m}$.

54 cultures, the mean tube number was $167 \pm 37$. Endothelial cells were associated with extracellular matrix material: EDa + and EDb + fibronectins (Fig. 3), collagen I, and the basal lamina proteins, $\beta 1$ laminin and collagen iv (Fig. 2).

Ultrastructural studies confirmed the endothelial nature of the cells, because characteristic cigar-shaped Weibel-Palade bodies were observed. Ultrastructural studies also confirmed the tube formation (Fig. 4). Lumens were either filled or not filled with cellular debris, and they were limited by two or three endothelial cells with apposed membranes forming close
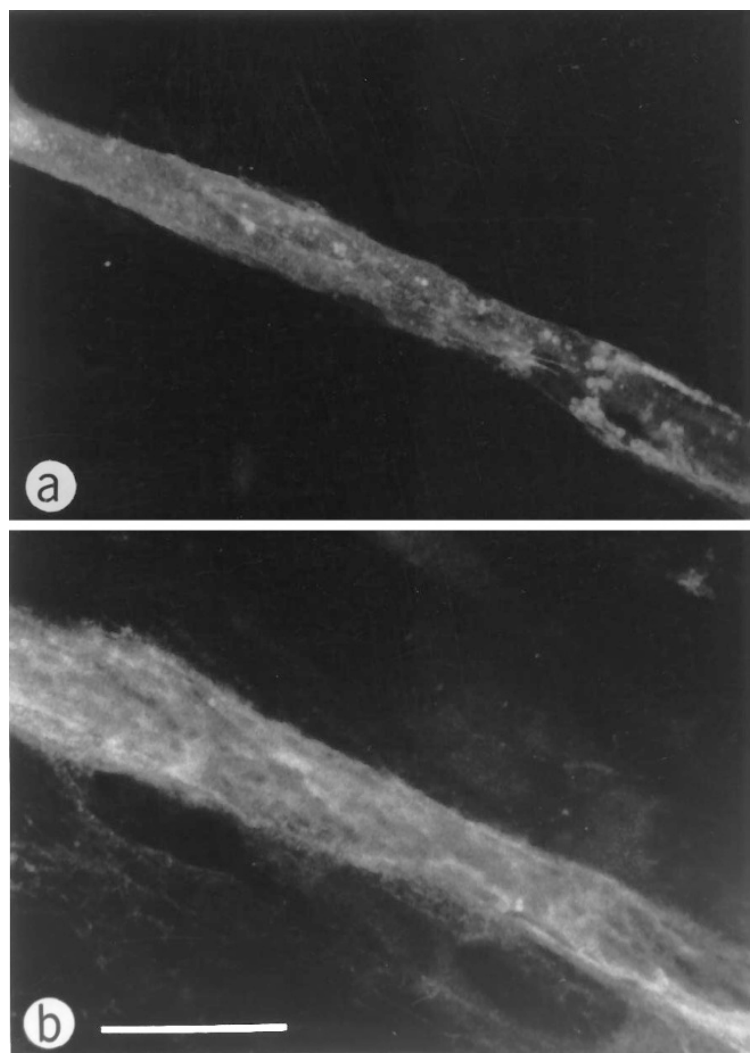

\section{Figure 3.}

Collagen iv-immunoreactive basal matrix surrounding endothelial tubes. Double-labeling of an endothelial tube with FITC-conjugated Ulex europaeus agglutinin-1 (UEA-1) (a) and a TRITC-conjugated type iv collagen antibody (b). The UEA-1-immunoreactive endothelial cells forming the tube are ensheathed in a basal lamina of fibrillar aspect comprised of type iv collagen. Scale bar = $5 \mu \mathrm{m}$.

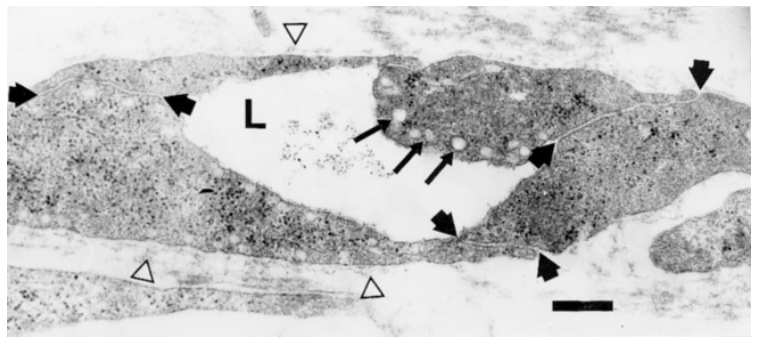

Figure 4.

Ultrastructure of an endothelial tube. On this transverse section, we can observe a typical organization of 4 endothelial cells into a tube around a capillary lumen (L). Solid arrows indicate cell junctions. Endocytic vesicles (small arrows) are observed beneath the luminal cell membrane. The tube is surrounded by a basal membrane (empty arrowheads). Scale bar $=1 \mu \mathrm{m}$.

junctions. A basement membrane was usually observed on the non-luminal side of the endothelial cells.

\section{Tubes are Surrounded by Pericytes Amidst Mesenchymal Stromal Cells}

Stromal cells, clearly not endothelial by any of the characteristics mentioned above, were observed among the tube-forming endothelial cells. These cells were 1B10 immunoreactive, and expressed prolyl-5- 
hydroxylase and vimentin, confirming their mesenchymal nature. The cells closest to the tubes, that were dendritic, were immunoreactive for membrane chondroitin sulfate proteoglycans, and expressed $\alpha$-SM actin in thin and tortuous microfilaments, were characterized as pericytes (Fig. 5).

There was a significant correlation (54 cultures analyzed; $r^{2}>0.38 ; p<0.001$ ) between the number of tubes observed in a culture and the number of $\alpha$-SM actin-expressing pericytes. Therefore, tubes and pericytes developed in parallel. It was observed that sprouting cells were either endothelial cells or pericytes, because they expressed either L-fucose residues or $\alpha$-SM actin. This suggested that pericytes were instrumental in endothelial cell organization.

\section{Key Molecules Involved in Basal Angiogenesis}

The culture conditions to generate capillary tubeforming endothelial cells required coating the culture flasks with type I collagen and plasma fibronectin. The growth media required the addition of low amounts of fetal calf serum (2\%) to E-Stim medium that of Endo-
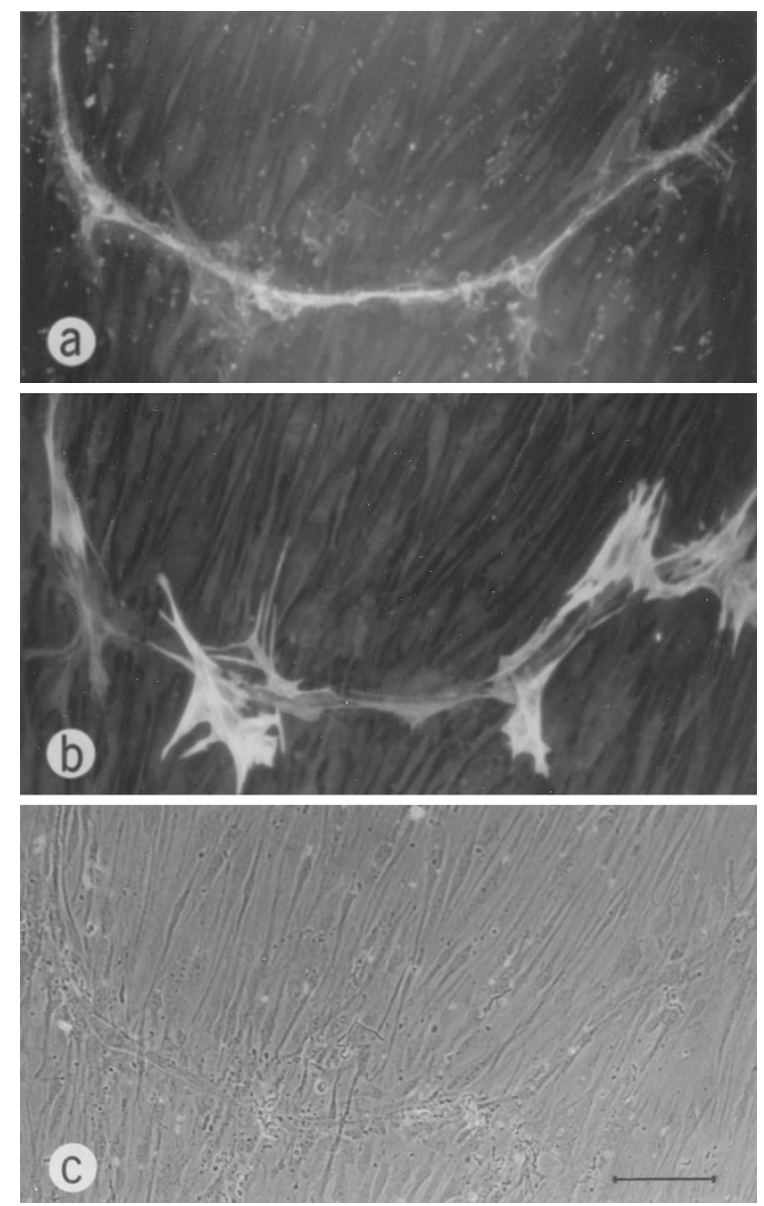

\section{Figure 5.}

Colocalization of pericytes and endothelial cells. Double labeling with a FITC-conjugated polyclonal antibody to VWF (a) and a Cy3-conjugated monoclonal antibody to $\alpha \mathrm{SM}$ actin (b). Corresponding phase contrast photomicrograph (c). The endothelial tube developing among stromal cells is associated with approximately $12 \alpha \mathrm{SM}$ actin-expressing pericytes (b). Scale bar $=5 \mu \mathrm{m}$. thelial Cell Growth Supplement (a mixture of fibroblast growth factors), and of heparin. However, tubes were also observed, although in decreased numbers, when cells were grown in M199 with $10 \%$ fetal bovine serum, or when flasks were not coated with collagen I or fibronectin.

Because these are the minimum requirements for tube formation, we asked two questions: 1) whether the addition of supplementary cytokines or other mediators would improve tube formation, and 2) whether we could identify key factors known to be involved in angiogenesis. To answer these questions, we either added or immunoneutralized factors that have been shown to modulate angiogenesis in other models.

Blocking either tissue-type (tPA) or urokinase-type (UPA) plasminogen activators with specific neutralizing antibodies resulted in a mean $20 \%$ decrease in tube formation. These results, however, were not significant at the $p<0.05$ level (Fig. 6).

The maximal effect of $\alpha \mathrm{v} \beta 3$ integrin immunoneutralization was found with application of $10 \mu \mathrm{g} / \mathrm{ml}$ of antibody. This resulted in a small (approximately 10\%) and not significant decrease in tube number compared with controls (Fig. 6). In contrast, immunoneutralization of $\alpha \mathrm{v} \beta 5$ integrin with $10 \mu \mathrm{g} / \mathrm{ml}$ of antibody significantly $(p<0.01)$ decreased capillary-tube formation by $26 \pm 7 \%$.

The addition of 1 to $10 \mathrm{ng} / \mathrm{ml}$ of recombinant human transforming growth factor beta (TGF $\beta$ )-1 (Fig. 7), or the addition of $10 \mu \mathrm{g} / \mathrm{ml}$ of anti-TGF $\beta$ neutralizing antibody (Fig. 6) did not modify tube formation. When $1 \mathrm{ng} / \mathrm{ml}$ of bFGF was added (Fig. 7), tube development was significantly reduced, to $87 \pm 10 \%$ of control levels $(p<0.05)$, whereas the addition of $5 \mu \mathrm{g} / \mathrm{ml}$ of anti-bFGF neutralizing antibody was without effect (Fig. 6). PDGF-BB and VEGF ${ }_{165}$ had comparable angiogenic properties; $1 \mathrm{ng} / \mathrm{ml}$ of PDGF-BB induced an

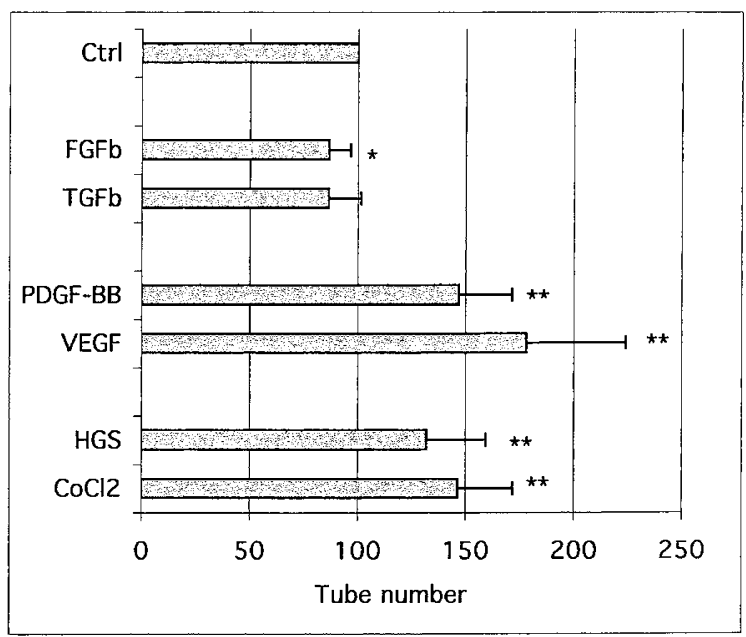

Figure 6.

Effect of different mediators on basal angiogenesis. Tubes were counted after labeling, as described for Figure 6 . The maximal effect is shown for bFGF ( 1 $\mathrm{ng} / \mathrm{ml})$, TGF $\beta(1 \mathrm{ng} / \mathrm{ml})$, PDGF-BB $(1 \mathrm{ng} / \mathrm{ml})$, VEGF $(1 \mathrm{ng} / \mathrm{ml})$, hydroxyguanidine sulfate (NO donor; $10 \mu \mathrm{M}$ ), and $\mathrm{CoCl}_{2}$ (Hypoxia mimetic; $10 \mu \mathrm{M}$ ). 


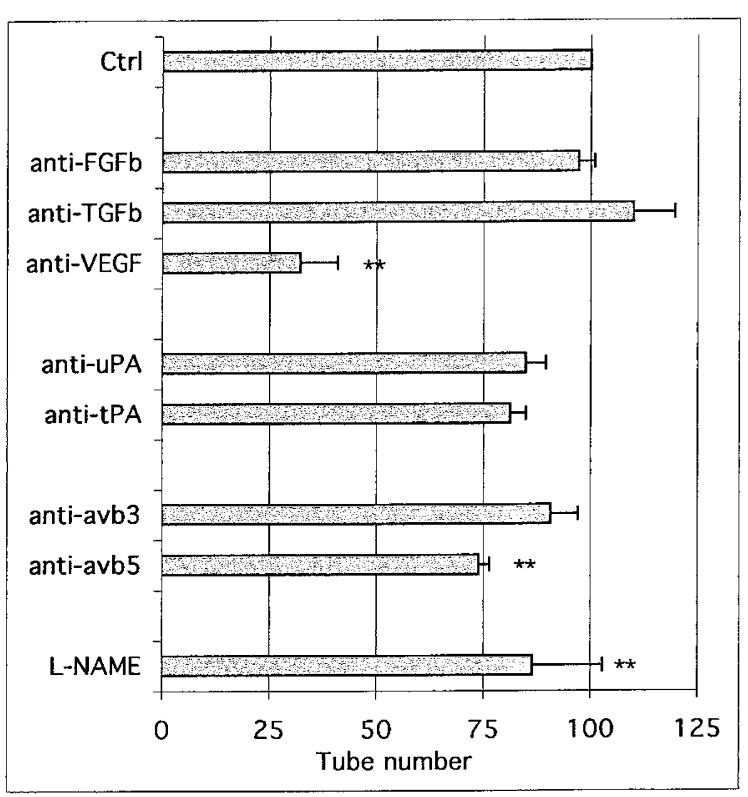

\section{Figure 7.}

Neutralization of mediators. Tubes were counted after labeling with anti-vWF; numbers are expressed as the percentage of the values found in the control conditions (in the absence of any added mediators except for those regarded as the minimum requirements, see methods). The maximal effect is shown for $5 \mu \mathrm{g} / \mathrm{ml}$ of anti-bFGF-, $10 \mu \mathrm{g} / \mathrm{ml}$ of anti-TGF $\beta-, 0.3 \mu \mathrm{g} / \mathrm{ml}$ of anti-VEGF-, 1 $\mu \mathrm{g} / \mathrm{ml}$ of anti-uPA-, $10 \mu \mathrm{g} / \mathrm{ml}$ of anti-tPA-, $10 \mu \mathrm{g} / \mathrm{ml}$ of anti- $\alpha v \beta 5$ - and 10 $\mu \mathrm{g} / \mathrm{ml}$ of anti- $\alpha v \beta 3$-neutralizing antibodies, and for $1 \mathrm{mM}$ L-NAME (NOS inhibitor).

increase in tube number by $47 \pm 25 \%(p<0.01)$, and $1 \mathrm{ng} / \mathrm{ml}$ of VEGF $_{165}$ induced an increase in tube number by $78 \pm 46 \%(p<0.01)$. We could not procure PDGF antibodies able to neutralize endogenous PDGF activity. Neutralization of VEGF in the culture medium dramatically reduced tube formation (Fig. 6); the number of tubes decreased to values as low as $32 \pm 9 \%$ of controls with $0.3 \mu \mathrm{g} / \mathrm{ml}$ of VEGF antibody $(p<0.01)$. Moreover, the neutralization of VEGF significantly decreased $(p<0.05)$ the number of tubes with $\alpha$-SM-expressing pericytes by $30 \pm 23 \%$, and decreased the number of tubes without pericytes $(p<0.01)$ by $59 \pm 4 \%$. As a result, the proportion of tubes associated with $\alpha$-SM-expressing cells significantly $(p<0.01)$ increased from $26 \pm 6 \%$ to $41 \pm 6 \%$ after VEGF neutralization.

The diffusible gas nitric oxide (NO) has been shown to be involved in several aspects of vascular physiology, particularly in vascular network growth (Gooch et al, 1997). In the presence of a NO stabilizer, hydroxyguanidine sulfate, angiogenesis was significantly $(p<$ 0.01 ) stimulated by $31 \pm 27 \%$ (Fig. 7 ). The inhibition of NO production by endothelial cell NO synthase, through the addition of $1 \mathrm{~mm}$ of L-NAME (Fig. 6) to the culture medium, resulted in a significant $(p<0.01)$ decrease in tube number by $14 \pm 17 \%$.

The addition of $10 \mu \mathrm{M} \mathrm{CoCl}{ }_{2}$, which mimics some aspects of hypoxia (Ma et al, 1998), induced a significant $(p<0.01)$ increase in tube number, $46 \pm 25 \%$ (Fig. 7).
Hematopoietic Cytokines Induce Major Increases in Tube Numbers

Because the formation of capillary tubes was associated with the stromal cells known to produce hematopoietic cytokines, and because of the known effect of some of these growth factors on marrow blood flow (Iversen et al, 1992; 1993), we examined whether some of these cytokines were also able to modulate angiogenesis (Fig. 8).

Stem Cell Factor (SCF) significantly increased ( $p<$ 0.01 ) tube formation by $27 \pm 16 \%$ at $0.1 \mathrm{ng} / \mathrm{ml}$ (Fig. 8). Higher concentrations resulted in lower stimulation. Both G-CSF and granulomonocytic colony stimulating factor (GM-CSF) at $10 \mathrm{ng} / \mathrm{ml}$ increased tube development, by $65 \pm 27 \%(p<0.01)$ and $42 \pm 25 \%(p<$ 0.01 ), respectively (Fig. 8). This angiogenic effect was larger for higher doses $(198 \pm 37 \%$ and $159 \pm 29 \%$ at $100 \mathrm{ng} / \mathrm{ml}$, for G-CSF and GM-CSF, respectively). The addition of $1 \mathrm{U} / \mathrm{ml}$ of EPO to cultures induced a $52 \pm$ $30 \%(p<0.01)$ increase in tube number (Fig. 8) and $10 \mathrm{U} / \mathrm{ml}$ of EPO induced a doubling in the number of tubes $(203 \pm 42 \% ; p<0.01)$.

No synergy or additive effect was found between SCF and the other three cytokines. The addition of up to $10 \mu \mathrm{g} / \mathrm{ml}$ of neutralizing antibodies to G-CSF or GM-CSF did not decrease tube numbers.

\section{Discussion}

We have generated a culture system of human bone marrow cells which includes two major elements of the hematopoietic microenvironment, endothelial cells organized into tubes and surrounding pericytes. The appearance of foci at the onset of the culture, the linear relationship between the foci and the plated cells (one colony per 8000 endothelial cells), and the reproducible reappearance of endothelial cells with tube-forming capacity after each passage, argue for the existence of a subpopulation of bone marrow angioblasts. Circulating angiogenic precursors of endothelial cells contribute to angiogenesis after damage secondary to ischemia in mice and dogs (Asahara

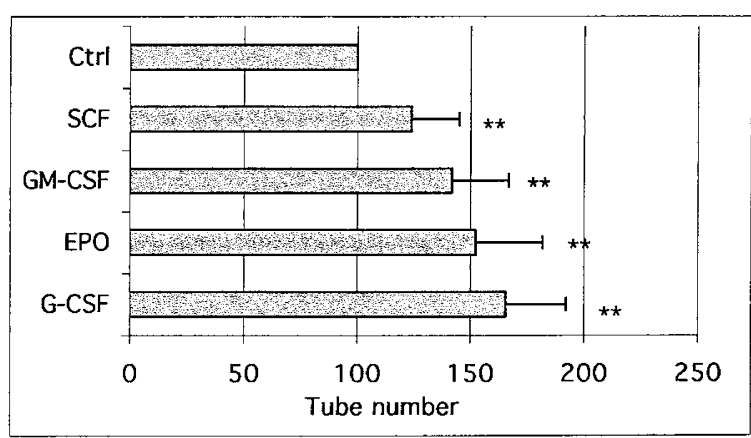

Figure 8.

Effect of hematopoietic cytokines. Tubes were counted after labeling, as described for fig 6. Effect on tube development of $0.1 \mathrm{ng} / \mathrm{ml}$ of SCF, $10 \mathrm{ng} / \mathrm{ml}$ of GM-CSF, $1 \mathrm{U} / \mathrm{ml}$ of EPO, and $10 \mathrm{ng} / \mathrm{ml}$ of G-CSF. The maximal effect is presented for SCF and GM-CSF. For EPO and G-CSF, even higher stimulation was observed for cytokine concentration $(200 \%$ of control value for $10 \mathrm{U} / \mathrm{ml}$ and $100 \mathrm{ng} / \mathrm{ml}$, respectively). 
et al, 1997; Shi et al, 1998). In dogs, it has been suggested that the angioblasts were of marrow origin. Further studies should indicate whether the angioblasts in our culture system are also able to circulate.

Most models of in vitro angiogenesis are cultures of endothelial cells from different origins plated on extracellular matrix-coated surfaces or in an extracellular matrix protein gel (Baatout, 1997; Kubota et al, 1988; Montesano and Orci, 1987; Montesano et al, 1985). In these models, despite the presence of extracellular matrix molecules, the onset of angiogenesis usually requires stimulation by growth factors and/or phorbol esters. However, tube formation is consistently and reproducibly observed in our system. Because our culture requirements are not fundamentally different from those used in other systems, consistent tube formation is probably linked to the simultaneous presence of mesenchymal cells. The ability of these endothelial cells to organize themselves even when using another culture medium (M199 with 10\% fetal bovine serum), without any matrix, or when the matrix composition is modified (gelatin, collagen I or fibronectin alone) is in agreement with this hypothesis. The colocalization of pericytes (a subpopulation of mesenchymal cells) with endothelial tubes; the highly significant correlation between the number of tubes and the number of $\alpha \mathrm{SM}$ actin-expressing pericytes; and the ability of both pericytes and endothelial cells to give rise to sprouts at the tips of the tubes all further reinforce the hypothesis of an interaction between the two cell populations. Moreover, in maturing blood vessels, endothelial cells recruit periendothelial mesenchymal cells that differentiate either into smooth muscle cells or into pericytes expressing $\alpha \mathrm{SM}$ actin. Mesenchymal cells, and more specifically, pericytes, may be involved at the different stages of angiogenesis: endothelial cell proliferation, organization into tubes, and tube stabilization (for review, see Beck and D'Amore, 1997; Hirschi and D'Amore, 1997). In our system, a reciprocal relationship between mesenchymal cells and endothelial cells seems likely, with endothelial cells being able to induce both $\alpha$ SM actin gene expression and pericyte generation from mesenchymal cells.

Angiogenesis is a complex process which involves basal lamina formation and remodeling, the presence of cell adhesion molecules, different sets of cytokines, and tone modulators (Beck and D'Amore, 1997). We tried to determine some of the key factors involved in our system.

Extracellular matrix plays a double role in angiogenesis: it is a material that has to be remodeled and built up during cell migration and organization, but it is also an informative support material that is involved in the balance between the angiogenic and quiescent states (Ingber, 1991). In our system, the basal lamina was made of collagen iv, laminin $\beta 1$, and EDa + and EDb + fibronectin, an expected composition for vascular tubes (Castellani et al, 1995; Paulsson, 1992). Alternative splicing generates $\mathrm{EDa}+$ and $\mathrm{EDb}+$ fibronectin isoforms. The isoform containing the EDb sequence is regarded as oncofetal because it is undetectable in normal adult tissues, but is expressed in fetal and tumor tissues. Moreover, this production is restricted to new vessels, and thus is a marker for angiogenesis (Castellani et al, 1995). This study did not provide evidence for basal membrane remodeling because treatment of cultures with antibodies directed against either UPA or TPA induced only a 15\% (not significant) decrease in the formation of capillary tubes. In this respect, our system differs from that of other human microvascular endothelial cells where tPA activity has been shown to be required for growth factor-induced tube formation (Sato et al, 1993). In our system, whether proteolytic activity is not absolutely required for tube formation, or whether matrix metalloproteases contribute primarily to this activity has not been determined.

The integrins are key factors of angiogenesis (for review, see Beauvais-Jouneau and Thiery, 1997). Brooks et al have shown that $\alpha_{\mathrm{v}} \beta_{3}$ is restrictively expressed by angiogenic endothelial cells and that its blockade using neutralizing antibodies inhibited bFGF-induced angiogenesis without harming preexisting vessels (Brooks et al, 1994; 1995). However, $\alpha_{\mathrm{v}} \beta_{3}$ blocking had no effect on VEGF-induced angiogenesis (Friedlander et al, 1995), indicating $\alpha_{\mathrm{v}} \beta_{3}$-independent, but $\alpha_{v} \beta_{5}$-dependent, pathways for vessel development. In our system, although $\alpha_{\mathrm{v}} \beta_{3}$ was expressed by endothelial cells, the blockade of this pathway did not impair tube formation, in contrast to $\alpha_{\mathrm{v}} \beta_{5}$ blockade, which induced a significant $16 \%$ decrease. These results suggest that VEGF, not bFGF, is crucial in our culture conditions.

The first well characterized angiogenic factor was bFGF (for review, see Bussolino et al, 1996). In our model, the immunoneutralization of bFGF had no consequence, whereas the addition of bFGF (in addition to Endothelial Cell Growth Supplement) caused a slight but significant decrease in tube number. Because bFGF is a potent growth factor for marrow stromal cells (Sensebe et al, 1995), it might have favored the growth of stromal cells more than endothelial cells.

Since it was described in 1989, VEGF has proven to be the most potent angiogenic factor. In our model, VEGF plays a key role, because addition of $1 \mathrm{ng} / \mathrm{ml}$ of VEGF significantly increased the number of capillary tubes by $78 \%$, and, conversely, VEGF neutralization reduced the number of capillary tubes to values lower than before antibody treatment. These data strongly suggest that VEGF is a survival factor for angiogenic vessels from adult marrow, as observed for endothelial cells during hypoxic or tumoral development (Aiello et al, 1995; Benjamin and Keshet, 1997). As observed in other systems, VEGF might prevent the apoptosis of marrow endothelial cells committed to angiogenic process (Alon et al, 1995). We also observed that, although the total tube number decreased in the presence of anti-VEGF, the proportion of pericyteassociated tubes significantly increased, from $26 \%$ to $43 \%$, indicating that the decrease in tubes was mainly due to a selective loss of tubes devoid of pericytes. Thus, our data add further in vitro evidence that 
immature tubes present a greater sensitivity to VEGF withdrawal (Benjamin et al, 1999).

The major regulator of VEGF synthesis and release is hypoxia (Shweiki et al, 1992). We found indirect evidence that human bone marrow endothelial cells respond to ischemia, because addition of $\mathrm{CoCl}_{2}$, which mimics hypoxia (Ma et al, 1998), actually increased the tube number by more than $40 \%$.

VEGF was first described as a vascular permeability factor because it induces significant vessel leakage (Senger et al, 1983). Endothelium Derived Releasing Factor, a central vasodilator identified as diffusible $\mathrm{NO}$, also modifies the permeability of vessels (Palmer et al, 1987). In our system, the NO stabilizer, hydroxyguanidine sulfate, significantly increased the number of capillary tubes, by $30 \%$, whereas inhibition of $\mathrm{NO}$ production by L-NAME significantly reduced this number, by $15 \%$. Whether or not NO contribution to human marrow angiogenesis is controlled by VEGF, as suggested in other systems (Morbidelli et al, 1996), has not been addressed.

We conclude that VEGF seems to play a critical role for in vitro human bone marrow angiogenesis. Stromal mesenchymal cells synthesize VEGF and probably also release this growth factor (Sensebe et al, 1997a). Hypoxia might increase the VEGF release, and VEGF is likely to act in concert with $\mathrm{NO}$ via the $\alpha_{\mathrm{v}} \beta_{5}$ integrin pathway.

PDGF has a dual potential because it is involved in abluminal cell recruitment and is also a microvascular endothelial cell mitogen (Beitz et al, 1991). In our model, addition of PDGF-BB induced a significant increase in the number of capillary tubes. PDGF-BB might increase the recruitment of pericytes from stromal mesenchymal cells and might also be a mitogen for endothelial cells. In the absence of PDGF-BB neutralizing antibody, we could not assess whether PDGF-BB plays an active role under basal conditions of culture.

TGF $\beta 1$, another factor involved in angiogenesis (Beck and D'Amore, 1997), is produced when endothelial cells interact with mural cells (Antonelli-Orlidge et al, 1989; Orlidge and D'Amore, 1987; Sato and Rifkin, 1989). In our system neither addition nor neutralization of TGF $\beta$ affected tube formation. However, the differentiation from mesenchymal cells to pericytes in the immediate vicinity of endothelial cells forming tubes indicates the relevance of cell to cell contact for maturation. Although TGF $\beta 1$ is probably critical for this maturation step (Beck and D'Amore, 1997), it is possible that we were unable to neutralize the $0.17 \mathrm{ng} / \mathrm{ml}$ of active TGF $\beta 1$ provided by the serum.

The hematopoietic cytokines G-CSF, GM-CSF, and EPO have been proven to be growth factors for human umbilical and rat aortic macrovascular endothelial cells, and been proven to play a major role in regulating blood supply to bone marrow and hence in the release of mature blood cells (Anagnostou et al, 1990; Bussolino et al, 1991; Carlini et al, 1995). In this work, we observed that G-CSF, GM-CSF, and EPO increased the number of capillary tubes by $65 \%, 41 \%$, and $52 \%$ respectively. Moreover, addition of $0.1 \mathrm{ng} / \mathrm{ml}$ of SCF also increased the tube number by $27 \%$. To our knowledge, an angiogenic role of SCF has not been reported yet, and might be specific for marrow microvascular cells. We must emphasize that the effect of SCF was observed for values as low as 0.1 $\mathrm{ng} / \mathrm{ml}$, and effects with increasing concentrations were not found. Moreover, SCF added to G-CSF, GM-CSF, or EPO was not found to be synergistic with the effects of these hematopoietic cytokines. These data underscore some of the major differences between the effect of SCF on endothelial cells in our culture system and its effect on hematopoietic colonies (Broudy, 1997).

G-CSF and EPO were potent angiogenic factors in our culture conditions. G-CSF $(100 \mathrm{ng} / \mathrm{ml})$ and EPO $(10 \mathrm{U} / \mathrm{ml})$ induced a $100 \%$ increase in the number of tubes (versus a maximum increase of $78 \%$ using 0.1 $\mathrm{ng} / \mathrm{ml}$ of VEGF, the optimal concentration for capillary tube increase). Marrow stromal cells are known to synthesize G-CSF, GM-CSF, EPO, and SCF (Bulabois et al, 1998; Sensebe, et al, 1997a; 1997b). However, G-CSF synthesis is observed only after induction by inflammatory cytokines; EPO and SCF synthesis is variable from one layer to the other or when induced by IL-1; and GM-CSF release is minimal in the absence of IL-1. Therefore, it was not surprising to observe that neutralization of these cytokines did not modify the number of tubes, which suggests that stromal mesenchymal cells did not release substantial amounts of these growth factors under basal conditions.

In conclusion, this work describes capillary tube formation by human marrow microvascular endothelial cells in the presence of mesenchymal stromal cells and pericytes. In this model, VEGF seems to play a key role, in concert with the $\alpha_{\mathrm{v}} \beta_{5}$ pathway and the production of NO. Pericytes involved in the maturation of tubes partially suppress the VEGF requirement for endothelial cells. The hematopoietic cytokines G-CSF, GM-CSF, and EPO are potent enhancers of tube formation. SCF also increases the number of tubes, an as yet undescribed function for this hematopoietic growth factor.

\section{Materials and Methods}

\section{Endothelial Cell Isolation and Culture}

Sternal bone marrow aspirates were obtained from patients undergoing cardiac surgery, after informed consent. The aspirates were collected in glass bottles containing heparin (100 I.U./bottle). Endothelial cells were isolated using a method derived from that described by Rafii et al (Rafii et al, 1994).

Marrow aspirates were centrifuged. The fat supernatant was recovered using albumin-coated pipettes and digested by $0.1 \%$ collagenase (Type I collagenase, Sigma Chemical Company, St Louis, Missouri) for 1 hour at $37^{\circ} \mathrm{C}$. The cells were then passaged through a $0.5 \mathrm{~mm}$ needle, washed once in phosphate buffered saline (PBS) and resuspended in $5 \mathrm{ml}$ of RPMI (BioWhittaker-Europe, Verviers, Belgium) sup- 
Table 1. Antibodies, Growth Factors, Cytokines, and othe Reagents Used for this Study

\begin{tabular}{|c|c|c|c|c|}
\hline \multirow[b]{2}{*}{ Product } & \multirow[b]{2}{*}{ Source } & \multicolumn{3}{|c|}{ Concentration for Studies } \\
\hline & & I.F. & F.C. & Function \\
\hline MoAb anti-CD34 (8G12) & Becton Dickinson & $1 / 40$ & $1 / 40$ & l \\
\hline MoAb anti-CD31 (JC/70A) & Dako & $1 / 50$ & $1 / 40$ & 1 \\
\hline Polyclonal rabbit anti-vWF & Dako & $1 / 225$ & $1 / 225$ & I \\
\hline MoAb anti- $\alpha$ SM (1A4) & Sigma & $1 / 200$ & 1 & 1 \\
\hline MoAb anti-FGFb (FB8) & Sigma & 1 & l & $1-15 \mu \mathrm{g} / \mathrm{ml}$ \\
\hline Polyclonal rabbit anti-TGF $\beta$ & R\&D Systems & l & l & $1-10 \mu \mathrm{g} / \mathrm{ml}$ \\
\hline MoAb anti-VEGF (26503.11) & Sigma & 1 & l & $0.1-5 \mu \mathrm{g} / \mathrm{ml}$ \\
\hline Polyclonal goat anti-tPA & Chemicon & I & l & $1-10 \mu \mathrm{g} / \mathrm{ml}$ \\
\hline Polyclonal rabbit anti-uPA & Dr P. Koolwijk & I & l & $1-10 \mu \mathrm{g} / \mathrm{ml}$ \\
\hline Polyclonal goat anti-hG-CSF & R\&D Systems & l & l & $0.1-10 \mu \mathrm{g} / \mathrm{ml}$ \\
\hline Polyclonal goat anti-hGM-CSF & R\&D Systems & l & I & $0.1-10 \mu \mathrm{g} / \mathrm{ml}$ \\
\hline MoAb anti-ICAM-1 (6.5B5) & Dako & l & $1 / 40$ & i \\
\hline MoAb anti-ICAM-2 (B-T1) & Immunotech & l & $1 / 40$ & I \\
\hline MoAb anti-VCAM-1 (1G11) & Immunotech & 1 & $1 / 40$ & l \\
\hline MoAb anti- $\alpha \vee \beta 3$ (LM609) & Chemicon & $1 / 100$ & I & $1-10 \mu \mathrm{g} / \mathrm{ml}$ \\
\hline MoAb anti- $\alpha \vee \beta 5$ (P1F6) & Chemicon & $1 / 100$ & I & $1-10 \mu \mathrm{g} / \mathrm{ml}$ \\
\hline MoAb anti-chondroitin sulfate (CS-56) & Sigma & $1 / 20$ & l & i \\
\hline MoAb anti-EDa+ FN (FN3E2) & Sigma & $1 / 100$ & l & l \\
\hline MoAb anti-EDb+ FN (BC-1) & Dr Zardi & $1 / 1$ & l & l \\
\hline Polyclonal goat anti-collagen IV & SBA & $1 / 10$ & l & l \\
\hline Polyclonal rabbit anti-Laminin & Institut Pasteur & $1 / 80$ & l & l \\
\hline MoAb anti-laminin $\beta 1$ & Dr. Rousselle & $1 / 100$ & l & 1 \\
\hline $\begin{array}{l}\text { MoAb anti-human fibroblast surface } \\
\text { protein (1B10) }\end{array}$ & Sigma & $1 / 100$ & 1 & l \\
\hline MoAb anti-Prolyl-4-hydroxylase (5B5) & Dako & $1 / 100$ & l & l \\
\hline MoAb anti-vimentin (VIM 13.2) & Sigma & $1 / 200$ & l & I \\
\hline Dil-Ac-LDL & Paesel Lorei & $1 / 50$ & $1 / 100$ & l \\
\hline Ulex europaeus agglutinin-1 (FITC) & Vector Laboratories & $1 / 50$ & $1 / 100$ & l \\
\hline rhVEGF & Becton Dickinson & 1 & 1 & $1-10 \mathrm{ng} / \mathrm{ml}$ \\
\hline rhPDGF-BB & Boehringer Mannheim & 1 & 1 & $1-10 \mathrm{ng} / \mathrm{ml}$ \\
\hline $\operatorname{rhTGF} \beta$ & R\&D Systems & l & I & $1-10 \mathrm{ng} / \mathrm{ml}$ \\
\hline rhFGFb & R\&D Systems & l & l & $1-10 \mathrm{ng} / \mathrm{ml}$ \\
\hline rhEPO & Boehringer Mannheim & l & l & $1-10 \mathrm{U} / \mathrm{ml}$ \\
\hline rhG-CSF & R\&D Systems & l & I & $0.1-100 \mathrm{ng} / \mathrm{m}$ \\
\hline rhGM-CSF & R\&D Systems & l & l & $0.1-100 \mathrm{ng} / \mathrm{ml}$ \\
\hline rhSCF & R\&D Systems & l & I & $1-10 \mathrm{ng} / \mathrm{ml}$ \\
\hline L-NAME & Sigma & 1 & 1 & $0.5-5 \mathrm{mM}$ \\
\hline Hydroxyguanidine sulfate & Sigma & I & l & $1-10 \mu \mathrm{M}$ \\
\hline $\mathrm{CoCl}_{2}$ & Sigma & 1 & 1 & $1-10 \mu \mathrm{M}$ \\
\hline Anti-mouse (FITC or TRITC) & Sigma & $1 / 150$ & $1 / 150$ & 1 \\
\hline Anti-rabbit (FITC or TRITC) & Sigma & $1 / 150$ & $1 / 150$ & l \\
\hline
\end{tabular}

plemented with $10 \%$ fetal bovine serum (FBS; GIBCO BRL, Gaithersburg, Missouri).

The selection of endothelial cells was performed using magnetic beads (M280 tosylactivated dynabeads, Dynal, Oslo, Norway) coated with Ulex europaeus agglutinin-1 (UEA-1; Vector Laboratories, Burlingame, California). Coating of the beads was performed by washing $6.7 \times 10^{8}$ beads once in PBS, incubating at room temperature for 20 hours in $1 \mathrm{ml}$ of PBS with 0.4 mg of UEA-1, washing twice in PBS, and resuspending in $2 \mathrm{ml}$ of PBS. Beads were stored at $4^{\circ} \mathrm{C}$ until use.

Coated beads were added to the cell suspension ( 1.5 bead per cell), and the targeted cells were recov- ered using a magnetic particle concentrator (MPC, Dynal). Cells were then washed three times in PBS and resuspended in E-Stim medium (Becton Dickinson, Bedford, Massachusetts).

Selected cells were cultured in $25 \mathrm{~cm}^{2}$ flasks (Becton Dickinson, Franklin Lakes, New Jersey) or on Lab Tek culture chamber slides (Eight-well permanox slides, Nunc, Illinois) coated with rat tail collagen type I (12 $\mu \mathrm{g} / \mathrm{cm}^{2}$, Becton Dickinson) and human plasma fibronectin (50 $\mu \mathrm{g} / \mathrm{cm}^{2}$, Becton Dickinson).

Cells were plated at $3.5 \times 10^{6}$ cells per $25 \mathrm{~cm}^{2}$ flask for primary culture. For secondary cultures, the cells were trypsinized and plated at either $0.5 \times 10^{6}$ cells per $25 \mathrm{~cm}^{2}$ flask or $1.2 \times 10^{4}$ cells per well of Lab Tek 
culture chamber slide. Cells were incubated at $37^{\circ} \mathrm{C}$ with $4 \% \mathrm{CO}_{2}$. The cell layers were predominantly studied after the first passage, but could be used through five passages.

\section{Immunofluorescence Studies}

The culture medium was removed from Lab Tek culture chambers and the monolayer was washed once with PBS prior to fixation. Cells were either fixed with $3.7 \%(\mathrm{v} / \mathrm{v})$ of formaldehyde in PBS for extracellular or plasma membrane labeling or permeabilized and fixed with cold methanol for intracellular labeling. In both cases, cells were fixed for 30 minutes at $4^{\circ} \mathrm{C}$. Cells were then incubated for 30 minutes at room temperature with a primary antibody, washed twice in PBS, incubated for 30 minutes at room temperature with a secondary antibody, and washed twice in PBS. Controls were incubated with an irrelevant primary antibody. The source and concentration for primary and secondary antibodies are listed in Table 1. Dilacetylated-low density lipoproteins (Paesel-Lorei, Hanau, Germany) were added to the culture medium two hours before cell analysis. An Aristoplan microscope (Leitz Wetzlar, Wetzlar, Germany) was used for observation.

\section{Flow Cytometry Studies}

After treatment with type I collagenase, cultured cells were recovered and washed twice in PBS. The labeling of cell suspensions was performed as described above for cells grown on Lab Tek chamber slides, according to concentrations indicated in Table 1. The analysis was performed using a FACScan (Becton Dickinson) with Lysis II software (Becton Dickinson).

\section{Functional Studies}

Treatments of cultures were performed daily from approximately day 7 (75\% confluence) to day 12 . Substances were added as 1/100 of the culture medium volume in vehicle (PBS with $0.5 \%(\mathrm{w} / \mathrm{v})$ bovine serum albumin (BSA, Sigma)). Controls contained vehicle only, irrelevant antibody of the same isotype, or non-immune serum for immunoneutralization assays. The effect was determined by comparing the number of endothelial tubes in treated and control wells after labeling with antibodies to von Willebrand Factor.

\section{Electron Microscopy}

Cultured layers were washed twice in PBS, fixed with $2 \%(\mathrm{v} / \mathrm{v})$ glutaraldehyde in $0.1 \mathrm{M}$ cacodylate buffer for 30 minutes at $4^{\circ} \mathrm{C}$, and washed for 24 hours at $4^{\circ} \mathrm{C}$ with $0.2 \mathrm{M}$ sucrose in $0.1 \mathrm{M}$ cacodylate buffer. Postfixation was performed with $1 \%$ osmic acid in $0.15 \mathrm{M}$ cacodylate buffer at $4^{\circ} \mathrm{C}$ for 15 minutes. Fixed preparations were dehydrated using a series of ethanol solutions from $70 \%$ to $100 \%$. After embedding in Epoxy (Fluka, Buchs, Switzerland), sections were cut using a Super NOVA ultramicrotome (LKB, Stockholm, Sweden). The grids were observed with 1200 EX transmission electron microscope (JEOL, France) in the $\ll$ Centre commun de microscopie électronique $\gg$ at Besançon.

\section{Statistical Analysis}

In the text, values are expressed as the mean \pm the standard error of the mean. Statistically significant differences between series were assessed by ANOVA using Statview software (Abacus Concepts, Berkeley, California).

\section{Acknowledgements}

We are grateful to Pr. J. P. Carbillet and Pr. B. Kantelip (Besancon, France) for their technical assistance in electron microscopy preparation. We are also indebted to Dr. Zardi (Torino, Italy) for providing the BC-1 monoclonal antibody, to Dr. Koolwijk (Leiden, The Netherlands) for providing the UPA polyclonal antibody, and to Dr. Rousselle (Lyons, France) for providing the monoclonal laminin $\beta 1$ antibody.

\section{References}

Adamson JW, Fialkow PJ, Murphy S, Prchal JF, and Steinmann L (1976). Polycythemia vera: Stem-cell and probable clonal origin of the disease. N Engl J Med 295:913-916.

Aiello LP, Pierce EA, Foley ED, Takagi H, Chen H, Riddle L, Ferrara N, King GL, and Smith LEH (1995). Suppression of retinal neovascularization in vivo by inhibition of vascular endothelial growth factor (VEGF) using soluble VEGFreceptor chimeric proteins. Proc Natl Acad Sci USA 92: 10457-10461.

Alon T, Hemo I, Itin A, Peper J, Stone J, and Keshet E (1995). Vascular endothelial growth factor acts as a survival factor for newly formed retinal vessels and has implications for retinopathy of prematurity. Nat Med 1:1024-1028.

Anagnostou A, Lee ES, Kessimian N, Levinson R, and Steiner $M$ (1990). Erythropoietin has a mitogenic and positive chemotactic effect on endothelial cells. Proc Natl Acad Sci USA 87:5978-5982.

Antonelli-Orlidge A, Saunders KB, Smith SR, and D'Amore PA (1989). An activated form of transforming growth factor beta is produced by cocultures of endothelial cells and pericytes. Proc Natl Acad Sci USA 86:4544-4548.

Asahara T, Murohara T, Sullivan A, Silver M, Van Der Zee R, Li T, Witzenbichler B, Schatterman G, and Isner JM (1997). Isolation of putative progenitor endothelial cell for angiogenesis. Science 275:964-967.

Baatout S (1997). Endothelial differentiation using Matrigel. Anticancer Res 17:451-456.

Beauvais-Jouneau A and Thiery JP (1997). Multiple roles for integrins during development. Biol Cell 89:5-11.

Beck L and D'Amore PA (1997). Vascular development: Cellular and molecular regulation. FASEB J 11:365-373.

Beitz JG, Kim IS, Calabressi P, and Frackelton AR (1991). Human microvascular endothelial cells express receptors for platelet-derived growth factor. Proc Natl Acad Sci USA 88:2021-2025. 
Benjamin LE, Golijanin D, Itin A, Pode D, and Keshet E (1999). Selective ablation of immature blood vessels in established human tumors follows vascular endothelial growth factor withdrawal. J Clin Invest 103:159-165.

Benjamin LE and Keshet E (1997). Conditional switching of vascular endothelial growth factor (VEGF) expression in tumors: Induction of endothelial cell shedding and regression of hemangioblastoma-like vessels by VEGF withdrawal. Proc Natl Acad Sci USA 94:8761-8766.

Brooks PC, Clark RAF, and Cheresh DA (1994). Requirement of vascular integrin alpha $v$ beta 3 for angiogenesis. Science 264:569-571.

Brooks PC, Stromblad S, Klemke R, Visscher D, Sarkar FH, and Cheresh DA (1995). Antiintegrin alpha $\vee$ beta 3 blocks human breast cancer growth and angiogenesis in human skin. J Clin Invest 96:1815-1822.

Broudy V (1997). Stem cell factor and hematopoiesis. Blood 90:1345-1364.

Bulabois CE, Yerly-Motta V, Mortensen BT, Fixe P, RemyMartin JP, Herve P, Tiberghien P, and Charbord P (1998). Retroviral-mediated marker gene transfer in hematopoiesissupportive marrow stromal cells. J Hematother 7:225-239.

Bussolino F, Albini A, Camussi G, Presta M, Viglietto G, Ziche $M$, and Persico $G$ (1996). Role of soluble mediators in angiogenesis. Eur J Cancer 32A:2401-2412.

Bussolino F, Ziche M, Wang JM, Alessi D, Morbidelli L, Cremona O, Bosia A, Marchisio MC, and Montovani A (1991). In vitro and in vivo activation of endothelial cells by colonystimulating factors. J Clin Invest 87:986-995.

Carlini RG, Reyes AA, and Rothstein M (1995). Recombinant human erythropoietin stimulates angiogenesis in vitro. Kidney Int 47:740-745.

Castellani P, Viale G, Dorcaratto A, Querze G, Allemanni G, Zardi L, and Siri A (1995). Specific expression of the ED-B containing fibronectin isoform by endothelial cells of growing tumor vessels. Antibody, Immunoconjugates, and Radiopharmaceuticals 8:325-332.

Charbord $P$ (1999). The microenvironmental cell population essential for the support of hematopoietic stem cells. In: Zon, $\mathrm{L}$ editor. Developmental biology of hematopoiesis. Oxford: Oxford University Press.

Charbord P, Tavian M, Humeau L, and Peault B (1996). Early ontogeny of the human marrow from long bones: An immunohistochemical study of hematopoiesis and its microenvironment. Blood 87:4109-4119.

Fiedler W, Graaven U, Ergun S, Verago S, Kilic N, Stockschlader M, and Hossfeld DK (1997). Vascular endothelial growth factor, a possible paracrine growth factor in human acute myeloid leukemia. Blood 89:1870-1875.

Folkman J (1996). Fighting cancer by attacking its blood supply. Sci Am 275:150-154.

Friedlander M, Brooks PC, Shaffer RW, Kincaid CM, Varner JA, and Cheresh DA (1995). Definition of two angiogenic pathways by distinct alpha $v$ integrins. Science $270: 1500-$ 1502.

Galmiche MC, Koteliansky VE, Briere J, Herve P, and Charbord P (1993). Stromal cells from human long-term marrow cultures are mesenchymal cells that differentiate following a vascular smooth muscle differentiation pathway. Blood 82: 66-76.
Gooch KJ, Dangler CA, and Frangos JA (1997). Exogenous, basal, and flow-induced nitric oxide production and endothelial cell proliferation. J Cell Physiol 171:252-258.

Groopman JE (1980). The pathogenesis of myelofibrosis in myeloproliferative disorders. Ann Intern Med 92:857-858.

Hirschi KK and D'Amore PA (1997). Control of angiogenesis by the pericyte: Molecular mechanisms and significance. EXS 79:419-428.

Ingber D (1991). Extracellular matrix and cell shape: Potential control points for inhibition of angiogenesis. J Cell Biochem $47: 236-241$

Ishikawa F, Miyazono K, Hellman U, Drexler H, Werntedt C, Hagiwara K, Usuki K, Takaku F, Risau W, and Heldin $\mathrm{CH}$ (1989). Identification of angiogenic activity and the cloning and expression of platelet-derived endothelial cell growth factor. Nature 338:557-562.

Iversen PO, Nicolaysen G, and Benestad HB (1992). Blood flow to bone marrow during development of anemia or polycythemia in the rat. Blood 79:594-601.

Iversen PO, Nicolaysen G, and Benestad HB (1993). The leukopoietic cytokine granulocyte colony-stimulating factor increases blood flow to rat bone marrow. Exp Hematol 21:231-235.

Jackson JR, Seed MP, Kircher CH, Willoughby DA, and Winkler JD (1997). The codependence of angiogenesis and chronic inflammation. FASEB J 11:457-465.

Jacobson RJ, Salo A, and Fialkow PJ (1978). Agnogenic myeloid metaplasia: A clonal proliferation of hematopoietic stem cells with secondary myelofibrosis. Blood 51:189-194.

Kubota Y, Kleinman HK, Martin GR, and Lawley TJ (1988). Role of laminin and basement membrane in the morphological differentiation of human endothelial cells into capillarylike structures. J Cell Biol 107:1589-1598.

Lichman MA (1984). The relationship of stromal cells in marrow. In: Wright DG and Greenberger JS, editors. Longterm bone marrow culture. New York, 3-29.

Ma J, Fei ZL, Klein-Szanto A, and Gallo JM (1998). Modulation of angiogenesis by human glioma xenograft models that differentially express vascular endothelial growth factor. Clin Exp Metastasis 16:559-568.

Montesano R, Mouron P, and Orci L (1985). Vascular outgrowths from tissue explants embedded in fibrin or collagen gels: A simple in vitro model of angiogenesis. Cell Biol Int Rep 9:869-875.

Montesano R and Orci L (1987). Phorbol esters induce angiogenesis in vitro from large-vessel endothelial cells. J Cell Physiol 130:284-291.

Morbidelli L, Chang CH, Douglas JG, Granger HJ, Ledda F, and Ziche M (1996). Nitric oxide mediates mitogenic effect of VEGF on coronary venular endothelium. Am J Physiol 270: $\mathrm{H} 411-\mathrm{H} 415$.

Orlidge A and D'Amore PA (1987). Inhibition of capillary endothelial cell growth by pericytes and smooth muscle cells. J Cell Biol 105:1455-1462.

Palmer RM, Ferrige AG, and Moncada S (1987). Nitric oxide release accounts for the biological activity of endotheliumderived relaxing factor. Nature 327:524-526. 
Paulsson M (1992). Basement membrane proteins: Structure, assembly, and cellular interactions. Crit Rev Biochem Mol Biol 27:93-127.

Perez-Atayde A, Sallan SE, Tedraw U, Connors S, Allred E, and Folkman J (1997). Spectrum of tumor angiogenesis in the bone marrow of children with acute lymphoblastic leukemia. Am J Pathol 150:815-821.

Rafii S, Shapiro F, Rimarachin J, Nachman RL, Ferris B, Weksler B, Moore MAS, Asch AS (1994). Isolation and characterization of human bone marrow microvascular endothelial cells: Hematopoietic progenitor cell adhesion. Blood 84:10-19.

Reilly JT, Nash JRG, Mackie MJ, and McVerry BA (1985). Endothelial cell proliferation in myelofibrosis. $\mathrm{Br} \mathrm{J}$ Haematol 60:625-630.

Sato $Y$ and Rifkin DB (1989). Inhibition of endothelial cell movement by pericytes and smooth muscle cells: Activation of a latent transforming growth factor-beta 1-like molecule by plasmin during co-culture. J Cell Biol 109:309-315.

Sato Y, Okamura K, Morimoto A, Hamanaka R, Hamagushi K, Shimada T, Ono M, Kohno K, Sakata T, and Kuwano M (1993). Indispensable role of tissue-type plasminogen activator in growth factor-dependent tube formation of human microvascular endothelial cells in vitro. Exp Cell Res 204: 223-229.

Senger DR, Galli SJ, Dvorak AM, Perruzzi CA, Harvey VS, and Dvorak HF (1983). Tumor cells secrete a vascular permeability factor that promotes accumulation of ascites fluid. Science 219:983-985.
Sensebe L, Deschaseaux M, Li J, Herve P, and Charbord P (1997a). The broad spectrum of cytokine gene expression by myoid cells from the human marrow microenvironment. Stem Cells 15:133-143.

Sensebe L, Li J, Lilly M, Crittenden C, Herve P, Charbord P, and Singer JW (1995). Nontransformed colony-derived stromal cell lines from normal human marrows. I. Growth requirement and myelopoiesis supportive ability. Exp Hematol 23: 507-513.

Sensebe L, Mortensen BT, Fixe P, Herve P, and Charbord P (1997b). Cytokines active on granulomonopoiesis: Release and consumption by human marrow myoid stromal cells. Br J Haematol 98:274-282.

Shi Q, Rafii S, Wu MHD, Wijelath ES, Yu C, Ishida A, Fujita Y, Kothari S, Mohle R, Sauvage LR, Moore MAS, Storb RF, and Hammond WP (1998). Evidence for circulating bone marrowderived endothelial cells. Blood 92:362-367.

Shweiki D, Itin A, Soffer D, and Keshet E (1992). Vascular endothelial growth factor induced by hypoxia may mediate hypoxia-initiated angiogenesis. Nature 359:843-845.

Van Dyke D, Anger HO, Parker H, McRae J, and Dobson EL, Yano Y, Naets, JP, Linfoot J (1970). Markedly increased bone blood flow in myelofibrosis. J Nucl Med 12:506-512.

Wilson JG and Tavassoli M (1994). Microenvironmental factors involved in the establishment of erythropoiesis in bone marrow. Ann NY Acad Sci 718:271-284. 